\title{
Telaah Perilaku Salah Suai dalam Pendidikan Islam Anak Usia Dini
}

\author{
Annisa Rahmilah Bakri, Dwi Bhakti Indri M. \\ Institut Pesantren KH. Abdul Chalim \\ e-mail : annisarahmilah@gmail.com,indrimdwibhakti@gmail.com
}

\begin{abstract}
Abstrak
Pada saat sekarang ini masyarakat dibuat heran akan nilai - nilai kemanusiaan yang telah hilang saat ini. Anak - anak yang seharusnya merupakan generasi penerus bangsa telah dirusak masa depannya oleh perilaku orang - orang yang tidak bertanggung jawab. Media yang seharusnya gunakan untuk komunikasi di salah gunakan oleh orang - orang yang tidak bertanggung jawab. Terjadinya penyimpangan perikaku pada ada karena kurangnya komunikasi yang baik dengan orang tua, kurangnya pengawasan yang diberikan kepada anak, sehingga anak menjadi mudah terpengaruh dengan dunia luar tanpa pengawasan orang tua. Untuk menghindari semua hal tersebut diperlukan terjalinnya komunikasi yang baik antara orang tua dan anak,sehingga orang tua dapat mengetahui apa saja yang dilakukan oleh anak dan apa saja yang di rasakan oleh anak, terlebih lagi di era digital sekarang ini. Kondisi lingkungan dan juga orang tua sangat mempengaruhi perkembangan anak selanjutnya. Setelah semua hal itu menjadi satu bisa di pastikan bahwa akan mengurangiperilaku menyimpang pada anak. Apa lagi dengan anak - anak usia dini yang masih mudah untuk dipengaruhi, maka dari itu sangat diperlukan pengawasan - pengawasan dari orang tua maupun pendidik dalam mendidik anak, karena anak usia dini adalah imitasi terbaik, anak - anak akan sangat mudah meniru apa saja yang dilakukan oleh orang yang berada di sekitarnya apalagi hal tersebut adalah orang tuanya sendiri maka juga anak akan lebih mudah meniru. Maka dari itu orang tua perlu untuk menjaga sikap di dihadapan anak agar tidak terjadi perilaku menyimpang pada anak dan perkembangannya.
\end{abstract}

Kata Kunci : Anak, Perilaku maladaptive,Pola Asuh (Perilaku salah suai, pendidikan islam, anak usia dini).

\section{Pendahuluan}

Masyarakat saat ini semakin kritis, keingintahuan terhadap suatu masalah sangat tinggi. Diperlukannya kehadiran sarana komunikasi yang lebih dikenal sebagai media massa, sehingga dapat memenuhi kebutuhan manusia akan informasi. Media massa merupakan bagian dari struktur masyrakat, keduanya saling mempengaruhi dalam dinamika perkembangannya. Media massa atau dapat juga disebut sebagai komunikasi massa adalah merujuk pada keseluruhan intuisinya yang merupakan pembawa pesan, koran, majalah, stasiun pemancar, yang mampu menyampaikan pesan kepada jutaan orang nyaris serentak (William,2003). Masyarakat seakan dikejutkan oleh perilaku - perilaku yang menyimpang dari aspek moralitas bangsa ini. Fenomena ini terus meningkat 
dalam dua tahun terakhir, bukan hanya dari segi kuantitas tetapi juga dari segi kulitasnya. Tindakan kekerasan yang terjadi saat ini bukan hanya pada orang dewasa, melainkan sudah sampai pada taraf anak - anak. Beberapa kasus kekerasan terhadap anak - anak yang sangat memperihatinkan saat ini adalah bentuk kekerasan seksual. Komisi Perlindungan Anak Indonesia (KPAI) mengungkapkan bahwa pengaduan kasus kekerasan seksual terhadap anak mengingkat. Menurut data yang dimiliki Bidang Data Informasi dan Pengaduan KPAI, sepanjang tahun 2013, ada 502 aduan anak berhadapan dengan hukum $(\mathrm{ABH})$ untuk kasus kekerasan. Sebanyak 187 pengaduan dilakukan secara langsung, 40 melalui surat, 34 lewat telepon, dan 241 pengaduan via surat elektronik. Namun, Susanto selaku Ketua KPAI mengatakan, sejak Januari hingga Mei 2014, pengaduan mengenai kekerasan seksual terhadap anak sudah mencapai lebih dari 400 aduan. Selain pengaduan, KPAI juga melakukan pemantauan terhadap pemberitaan media massa mengenai kasus $\mathrm{ABH}$ dan kekerasan. KPAI berhasil mengumpulkan sekitar 502 berita di media daring (dalam jaringan), 342 berita di media cetak, dan 269 berita di media elektronik (MetroTv,2014). Satu per satu kasus pemberitaan mengenai kekerasan seksual pada anak mulai terungkap dari berbagai daerah di Indonesia. Tanpa mengingkari fungsi dan manfaat media massa dalam kehidupan masyarakat disadari adanya sejumlah efek sosial negative yang ditimbulkan oleh media massa. Keluarga merupakan lingkungan pertama dan utama bagi proses perkembangan seorang individu sekaligus merupakan peletak dasar kepribadian anak (Mila,2012). Oleh karena itu, keluarga sebagai lembaga pertama dan utama bagi pendidikan anak, mempunyai peranan penting dalam mengembangkan potensi anak. Setiap manusia yang menjadi bagian dari masyrakat senantiasa mempunyai ststus atau kedudukan yang akan menimbulkan suatu peran atau peranan. Jadi status merupakan posisi di dalam suau sistem sosial. Peran adalah perilaku yang terkait dengan status tersebut.

Pendidikan merupakan inti kesuksesan Umat Islam oleh sebeb itu masa depan dan nasib umat pada masa yang akan datang sangat tergantung kepada kualitas pendidikan generasi muda, anak - anak adalah tanaman hari ini yang dipetik buahnya pada masa yang akan datang. Oleh karena itu suatu kelaziman untuk mendidik dan menumbuhkan anak - anak diatas pertumbuhan yang islami 
dan pendidikan yang benar sehingga akan muncul pemimpin dan pejuang umat yang memberi manfaat bagi diri sendiri, orang tua, umat dan agama. Barang siapa yang menginginkan anak shalih yang merupakan karunia dari Allah SWT Yang Maha Tinggi dan Maha Mampu maka hendaklah berdoa kepada-Nya karena doa orang tua mustjab sehingga mereka nanti akan menjadi simpanan baginya setelah meninggal karena seluruh amal usaha anak Adam AS terputus kecuali dari tiga perkara diantaranya yang selalu mendoakan kedua orang tua (Kasyidi,2013). Orang tua adalah orang dewasa pertama bagi anak yang harus mau menerima terhadap segalah tingkah laku anaknya, tempat anak menggantungkan, tempat ia mengharapkan bantuan dalam pertumbuhan dan perkembangannya menuju kedewasaan, serta bertanggung jawab penuh terhadap kesukesan anak untuk hidup di masa depan. Orang tua memegang peranan penting untuk meningkatkan prestasi belajar anak tanpa dorongan dan rangsangan dari orang tua maka perkembangan dan prestasi belajar anak mengalami hambatan (Mila,2012). Peran orang tua seharusnya adalah sebagai orang pertama dalam meletakkan dasar dasar pendidikan terhadap anaknya. Orang tua juga harus bisa menciptakan situasi pengaruh perhatian orang tua dengan menanamkan norma - norma untuk dikembangkan dengan penuh keserasian, sehingga tercipta iklim atau suasana keakraban antara orang tua dan anak. Menurut Nucholis Majid dalam Jeffy (2011) peran orang tua adalah peran tingkah laku, teladan dan pola - pola hubungannya dengan anak yang dijiwai dan disemangati oleh nilai - nilai keagmaan yang menyeluruh. Anak adalah makhluk sosial seperti juga orang dewasa. Anak membutuhkan orang lain untuk dapat membantu mengembangkan kemampuannya. Karena anak lahir dengan segala kelemahan sehingga tanpa orang lain anak tidak mungkin dapat mencapai taraf kemanusiaan yang nomal. Menurut John Locke (dalam Gunarsa,1995) anak adalah pribadi yang masih bersih dan peka terhadap rangsangan - rangsangan yang berasal dari lingkungan. Augustinus (dalam Suryabrata,2000) yang dipandang sebagai peletak dasar permulaan psikologi anak, mengatakan bahwa anak tidaklah sama dengan orang dewasa, anak mempunyai kecenderungan untuk menyimpang dari hukum dan ketertiban yang disebabkan oleh keterbatasan pengetahuan dan pengertian terhadap realita kehidupan, anak - anak lebih muda belajar dengan contoh - 
contoh yang diterimanya dari aturan - aturan yang bersifat memaksa. Perkembangan adalah perubahan psikologis sebagai hasil dari proses pematangan fungsi psikis dan fisik pada diri anak, yang di tunjang oleh faktor lingkungan dan proses belajar dalam peredaran waktu tertentu menuju kedewasaan dari lingkungan yang banyak berpengaruh dalam kehidupan anak menuju dewasa (Mila,21012). Pada saat pertumbuhan juga pola asuh sangat mempengaruhi perkembangan dan pergaulan anak. Pola Asuh yang diterapkan orang tua dapat menjadi tolak ukur bagaimana anak kedepannya. Seperti pola asuh otoriter,permisif dan demokratis semua pola asuh yang di terapkan oleh orang tua akan berdampak pada anak nantinya. Maka dari itu orang tua harus pandai dalam menerapkan pola asuh kepada anak, agar tidak terjadi salah asuh. Pada penerapan pola asuh, tidak serta merta orang tua hanya menerapkan satu pola asuh saja tetapi bisa menggabungkan kesemua pola asuh tersebut sesuai dengan kondisi anak dan limgkungan.

\section{Anak Usia Dini}

Anak usia dini adalah individu yang sedang mengalami proses pertumbuhan dan perkembangan yang sangat pesat,bahkan dikatakan sebagai lompatan perkembangan (Mulyasa,2012). Anak usia dini memiliki rentang usia yang sangat berharga dibanding usia - usia selanjutnya karena perkembangan kecerdasannya sangat luar biasa. Usia tersebut merupakan fase kehidupan yang unik, dan berada pada masa proses perubahan berupa pertumbuhan, perkembangan, pematangan dan penyempurnaan, baik pada aspek jasmani maupun rohaninya yang berlangsung seumur hidup, bertahap, dan berkesinambungan. Anak usia dini berada dalam proses perkembangan (development) sebagai perubahan yang dialami oleh setiap manusia secara individual dan berlangsung sepanjang hayat, mulai dari masa konsepsi sampai meninggal dunia. Anak usia dini memiliki sifat yang unik karena di dunia ini tidak ada satupun anak yang sama,meskipun lahir kembar,mereka dilahirkan dengan potensi yang berbeda,memiliki kelebihan, kekurangan,bakat dan minat masing masing. Anak usia dini merupakan individu yang berbeda,unik, dan memiliki 
karakteristik tersendiri sesuai dengan tahapan usianya usia dini/prasekolah merupakan kesempatan emas bagi anak untuk belajar

\section{Perilaku Maladaptif}

Rumini \& Hastomo (2008) mengungkapkan bahwa gejala perilaku yang melanggar norma baik norma masyarakat, hukum dan yang lain dalam istilah psikologi disebut perilaku maladaptive. Perilaku maladaptive juga dapat dikatakan sebagai perbuatan dari individu yang tidak mampu menyesuaikan diri atau beradaptasi dengan keadaan sekeliling secara wajar (Yesti,2010). Misalnya yang bersangkutan memperlihatkan ketakutan, kecurigaan (paranoid), gangguan menilai realitas, gangguan dalam fungsi sosial dan pekerjaan. Perilaku maladaptive ini sering menimbulkan konflik, pertengkaran, tindak kekerasan dan perilaku antisosial lainnya terhadap orang - orang disekelilingnya (Devi,2017). Keberhasilan pencapaian tugas perkembangan tertentu diharapkan dapat melahirkan kebahagiaan dan kesuksesan bagi individu untuk menyelesaikan tugas - tugas berikutnya. Sebaliknya, kegagalan dalam mencapai tugas - tugas perkembangan itu dapat mengakibatkan ketidakbahagiaan bagi individu. Penolakan oleh masyarakat, dan kesuliatan dengan tugas - tugas berikutnya. Salah satu bentuk kegagalan pencapaian tugas - tugas perkembangan adalah munculnya perilaku maladaptive. Martin dan Pear (2015) mengemukakan bahwa perilaku adalah apapun yang dikatakan atau dilakukan seseorang. Secara teknis, perilaku adalah apapun aktivitas otot, kelenjar, atau aktivitas disebuah organisme. Perilaku adaptif adalah perilaku yang diterima oleh lingkungan baik keluarga, sekolah, dan masyarakat dan bermanfaat untuk perkembangan anak. Perilaku maladaptive adalah perilaku yang cenderung tidak diterima oleh lingkungan keluarga, masyarakat, dan cenderung merugikan (Sary, 2010)perkembangan anak. Perilaku maladaptive yang dilakukan oleh anak biasanya adalah meniru orang yang ada disekitarmya.

\section{Perilaku Maladaptif pada Anak Usia Dini}

Perilaku maladaptive pada anak usia tidaklah jauh dari kegiatan yang dilakukan oleh orang tua, lingkungan dan teman bermain anak. Terjadinya 
maladaptive pada anak di karena kan juga oleh pola asuh yang diterapkan oleh orang tua (Devi,2017). Anak adalah imitasi terbaik yang pernah ada. Maka dari itu terjadinya perilaku maladaptive pada anak juga harus terlebih dahulu kita mengetahu bagaimana lingkungan yang ditempati anak, teman anak bermain dan yang terpenting adalah bagaimana orang tua berperilaku kepada anaknya. Pola asuh yang diterapkan oleh orang tua juga sangat berpengaruh dalam perkembangan anak selanjutnya (Devi,2017). Seperti pola asuh otoriter, pola asuh otoriter adalah pola asuh yang menerapkan lebih kepada kekerasan dalam artian semua yang diinginkan oleh orang tua harus dilakukan oleh anak, tanpa adanya penolakan dari anak. Ketika anak di didik dengan pola asuh otoriter maka dampak negatifnya anak akan menjadi takut dan tertekan untuk melakukan eksplorasi karena takut dimarahi oleh orang tua, takut jika orang tua tidak mengijinkan dan sbg (Devi,2017). Tetapi dampak postifnya anak menjadi lebih disiplin, walau sebenarnya tidak baik untuk anak sendiri, dan juga anak akan melakukan hal yang sama kepada anaknya nanti. Kemudian selanjutnya pola asuh permisif adalah pola asuh yang membolehkan dalam melakukan segala hal tanpa adanya larangan atau batasan, dampak negatife nya adalah anak menjadi tidak tahu mana yang benar dan mana yang salah karena tidak adanya larangan dari orang tua anak juga tidak dapat bertanggung jawab dengan apa yang telah di perbuatnya (Devi,2017). Dampak positife nya yaitu anak menjadi merasa bahagia karena semua keinginannya tercapai dan juga tidak merasa tertekan. Dan yang terakhir adalah pola asuh demokratif adalah pola asuh yang paling baik di antara kedua pola asuh yang telah di bahas, karena pola asuh demokratif adalah pola asuh yang memberikan reward and punishment kepada anak ketika anak melakukan kesalahan maupun melakukan kebaikan (Devi,2017). Anak di ajak untuk bertanggung jawab dengan apa yang telah mereka pilih dan juga anak akan di beritahu ketika anak di beri punishment. Jadi anak akan mengetahui alasan dari hukuman yang diberikan oleh orang tua mereka. Maka dari itu anak akan lebih berfikir lagi dan tidak mengulangi perbuatannya lagi. Perilaku maladaptive tidak akan terjadi kepada anak jika orang tua dapat mengawasi anak mereka dengan sebaik mungkin dan membatasi pergaulan anak dengan anak yang telah atau sering melakukan perilaku maladptif kemudian orang tua harus juga bersikap baik 
kepada anak agar anak tidak mengikuti apa yang orang tua mereka lakukan. Maka dari itu orang tua harus memberikan motivasi dan juga stimulus kepada anak agar anak tidak melakukan perilaku maladaptive yang dapat merusak perkembagan anak selanjtnya. Karena ketika anak telah terbiasa melakukan perilaku maladaptive maka sampai nanti anak menjadi dewasa akan terus menerus melakukan perilaku maladaptive.

\section{Pendidikan Islam}

Keluarga adalah wadah pertama dan utama bagi pertumbuhan dan pengembangan anak (Kasyidi,2013). Keluarga menjadi lingkungan pendidikan pertama dan utama, sebab sebagian besar intraksi pendidikan anak bersumber dari keluarga. Kewajiban utama keluarga dalam pendidikan, yakni membangun pondasi akhlak dan pandangan hidup keagamaan (Kasyidi,2013). Menurut Sigmund Freud keluarga itu terbentuk karena adanya perkawinan pria dan wanita. Bahwa perkawinan itu menurut beliau adalah berdasarkan libido seksualis. Dengan demikian keluarga merupakan manifestasi daripada dorongan seksual sehingga landasan keluarga itu adalah kehidupan seksual suami istri.

Fungsi pendidikan dalam keluarga merupakan konsekuensi yang logis daripada pemeliharaan anak - anak yang dilahirkan di dalam keluarga. Proses sosialisasi dari seorang anak dimulai di dalam lingkungan keluarga. Dari lingkungan keluarga anak belajar berbahasa, mengumpulkan pengertin pengertian dan menggunakan nilai - nilai kebudayaan yang berlaku . keluarga dalam hubungan ini mempunyai fungsi meneruskan kebudayaan. Didikan yang diberikan di dalam keluarga pada masa kanak - kanak disesuaikan dengan daya tangkap dan sifat - sifat emosionalnya. Menurut Hasbullah fungsi pendidikan dalam keluarga,yaitu:

1. Pengalaman pertama masa kanak - kanak

2. Menjamin kehidupan emosional anak

3. Menanamkan dasar pendidikan moral

4. Memberikan dasar pendidikan sosial anak

5. Peletakan dasar - dasar keagamaan 
Metode pendidikan keluarga adalah yaitu sebagai berikut :

a. Pendidikan dengan keteladanan

Keteladanan dalam pendidikan adalah metode influentif yang paling meyakinkan keberhasilannya dalam mempersiapkan dan membentuk anak di dalam moral, spiritual dan sosial. Pendidikan dengan adat kebiasaan. Rasulullah SAW memerintahkan kepada pendidik untuk mengajarkan kata - kata Laa Ilaaha Illallah kepada anak didiknya, seperti yang diriwayatkan seperti yang diriwayatkan Al- Hakim dari Ibnu Abbas RA dari Rasulullah SAW bahwasannya beliau bersabda: "Ajarkanlah kepada anak - anak kalian kata - kata pertama dengan Laa Ilaaha Illallah”.

b. Pendidikan dengan nasihat

Metode lain yang penting dalam pendidikan, pembentukan keimanan, mempersiapkan moral,spiritual dan sosial anak adalah pendidikan dengan pemberian nasihat.

c. Pendidikan dengan memberi hukuman

Metode yang di pakai Islam dalam upaya memberikan hukuman kepada anak :

1) Lemah lembut dan kasih sayang

2) Menjaga tabiat anak yang salah dalam menggunakan hukuman

3) Dalam upaya memperbaiki, hendaknya dilakukan secara bertahap, dari yang paling ringan hingga yang paling keras.

Materi mendidik dalam pengertiannya yang luas adalah suatu materi pendidikan islam secara garis besar merupakan konseptualisasi dari fungsi umum manusia sebagai hamba Allah ( fungsi ibadah,aspek keberagamaan ) dan khalifahNya ( fungsi eksistensial ), sekaligus materi yang meliputi dan melingkupi seluruh potensi dasar manusia ( fitrah ). (Kasyidi,2013)

Materi pendidikan tersebut yang saling berkaitan dalam pendidikan keluarga, antara lain:

1. Pendidikan keimanan 
Yang dimaksud dengan pendidikan keimanan adalah, megikat anak dengan dasar - dasar iman, rukun islam dan dasar - dasar syariah, sejak anak mulai mengerti dan dapat memahami sesuatu.

2. Pendidikan akhlak

Yang dimaksud pendidikan akhlak adalah pendidikan tentang prinsip dasar akhlak dan keutamaan sikap serta watak yang harus dimiliki dan dijadikan kebiasaan oleh anak sejak masa pemula hingga menjadi seorang mukallaf. Jika sejak masa kanak - kanaknya, ia tumbuh dan berkembang dengan berpijak pada landasan iman kepada Allah dan terdidik untuk selalu takut,ingat, pasrah, meminta pertolongan dan berserah diri kepada-Nya, ia akan memiliki kemampuan dan bekal pengetahuan di dalam menerima setiap keutamaan dan kemuliaan, disamping terbiasa dengan sikap akhlak mulia. Kita mengetahui bahwa diri At- Tasturi menjadi baik karena pamannya telah mendidiknya agar selalu ingat, takut dan berlindung kepada Allah, yaitu dengan jalan memerintahkan untuk selalu mengulang kata - kata "Allah bersamaku,Allah melihatku, Allah menyaksikan aku."

3. Pendidikan jasmani

Menurut Asnelly ilyas, pendidikan jasmani adalah salah satu aspek pendidikan yang penting yang tidak dapat dipisahkan dari pendidikan yang lain. Selain itu, dikatakan bahwa pendidikan jasmani merupakan salah satu alat utama bagi pendidikan ruhani. Pendidikan jasmani ini maksudnya adalah pendidikan yang erat kaitannya dengan pertumbuhan dan kesehatan jasmani. (Kasyidi,2013) Dengan demikian dapat disimpulkan bahwa pendidikan jasmani ialah usaha seseorang untuk menjadikan tubuh yang sehat dan kuat agar tubuh dapat melakukan gerakan yang aktif dalam menjalankan perbuatan yang positif.

4. Pemeliharaan Akal

Semua orang memiliki otak dan otak bukanlah akal. Akal adalah daya kerja otak atau energy otak. Akal tidak pernah diam,selalu dinamis,beraktivitas. Proses kerja akal disebut dengan berfikir. Pendidikan akal akan menjadikan anak mampu berfikir logis, analitis dan inovatif dan tanggung jawab kemandirian berpikirnya. Akal mereka akan terdidik 
dengan disiplin - disiplin dan tidak manja, sehingga mereka dapat menganalisa persoalan dengan penuh kekeritisan dan ketajaman. Orang yang berpendidikan akal akan sentiasa beriorentasi dalam kehidupannya dengan semangat spiritualisme dengan rasionalitasnya, karena dalam agama islam sengat menekankan keduanya.

\section{Kesimpulan}

Dari berbagai penjelasan di atas dapat disimpulkan bahwa perilaku maladaptive dapat terjadi kepada anak karena mengenai beberapa faktor yaitu seperti keluarga, lingkungan dan teman anak dalam bermain. Selain itu pola asuh juga dapat mengakibatkan anak menjadi berperilaku maladaptive yang dapat berpengaruh dalam perkembangan anak selanjutnya. Maka dari itu, orang tua harus selalu memberikan motivasi kepada anak agar tidak terjadi perilaku maladaptive dan juga menerapkan pola asuh yang benar untuk anak. Selain itu pendidikan agama paling penting dalam pola asuh yang diberikan oleh orang tua karena penanaman pendidikan agama harus di terapkan kepada anak sedini mungkin.

\section{Saran}

Setelah penulis menulis artikel ini, semoga dapat menjadi pelajaran lagi bagi kita dan kita dapat menjadi pendidik atau orang tua yang lebih baik lagi untuk anak - anak kita agar tidak terjadi maladaptive pada anak kita. Setelah membaca tulisan ini diharapkan para pembaca memberikan saran agar dapat menjadi perubahan untuk penulis dan lebih memperbaikinya di tulisan selanjutnya

\section{DAFTAR PUSTAKA}

Anggraeni, M. (2012). Peran Orang Tua Dalam Menerapkan Table Manner Untuk Meningkatkan Aspek Perkembangan Anak Usia Dini.

Kasyidi, M. F. (2013). Pendidikan Keluarga Berbasis Tauhid, iv + 141 Halaman.

Mulayasa. (2012). Bandung: PT.Rosyda Karya. 
Odya, F., \& Yudiningrum, F. R. (2014). Terpaan Pemberitaan Kekerasan Seksual Pada Anak Terhadap Tingkat Kecemasan dan Perilaku Proteksi.

Pusat Kajian Bimbingan dan Koseling Unindra - Ikatan Konselor Indonesia. (2017). Jurnal Bimbingan dan Koseling vol. 1 No. 1, 78 - 88.

Ratnasari, D. (2017). Disain Interverensi dalam Konseling untuk Mereduksi Perilaku.

Rivers, W. R., Jasen, J. W., \& Peterson, T. (2003). Media Massa dan Msyarakat Modern. Jakarta: Kencana.

Sary, Y. K. (2010). Perilaku Maladptif dalam Proses Pembelajaran Siswa Kelas VIII Sekolah Menengah Pertama Negeri 23 Pekanbaru.

Widiasari, Y., \& Pujiati, D. (2016). Modifikasi Perilaku Pada Anak Usia Dini2016, 1693 $-1076$. 